\title{
Teknik Penanganan Kendali Hewan Sesuai Kaidah Kesejahteraan Hewan Meningkatkan Akurasi Pengukuran Profil Hemodinamika Tikus Laboratorium
}

\author{
(RESTRAINS METHOD BASED ON THE ANIMAL WELFARE PRINCIPAL \\ IMPROVED THE ACCURACY OF HEMODYNAMIC VALUE MEASUREMENTS \\ IN LABORATORY RAT)
}

\author{
Huda Shalahudin Darusman ${ }^{1,2,}$, , Setyo Widi Nugroho ${ }^{3,4}$, \\ Fauzi Abdurrahman Munggaran ${ }^{1}$, dan Dondin Sajuthi ${ }^{1,2}$ \\ ${ }^{1}$ Departemen Anatomi, Fisiologi, dan Farmakologi, \\ Fakultas Kedokteran Hewan, Institut Pertanian Bogor, \\ Jln Agathis Raya, Kampus IPB Darmaga, Bogor, Indonesia \\ Email: hudada@apps.ipb.ac.id \\ ${ }^{2}$ Pusat Studi Satwa Primata, \\ Lembaga Penelitian dan Pengabdian Masyarakat, IPB \\ Jalan Lodaya II No.5 Bogor, Indonesia \\ ${ }^{3}$ Divisi Vaskuler, Departemen Bedah Saraf, \\ Fakultas Kedokteran Universitas Indonesia, \\ Jalan Salemba Raya No. 6 Jakarta, Indonesia \\ ${ }^{4}$ Rumah Sakit Umum Pusat Nasional Cipto Mangunkusumo, \\ Jl. Diponegoro No. 71 Jakarta Pusat, Jakarta, Indonesia
}

\begin{abstract}
Abstrak
Pengukuran nilai hemodinamika dengan menggunakan apparatus (seperangkat alat) pengukur tekanan darah ekor berpotensi menimbulkan ketidaknyamanan kronik (chronic discomfort) mengingat hewan berada dalam corong apparatus yang memberikan ruang gerak sangat terbatas dan pengukuran berlangsung cukup lama, yaitu 10 kali ulangan pengukuran setiap sesi dan setiap pengukuran menghabiskan 1,5 menit. Penerapan kaidah kesejahteraan hewan (kesrawan) diharapkan dapat mengurangi potensi chronic discomfort yang ditimbulkan sehingga meningkatkan akurasi pengukuran hemodinamika yang dapat terganggu akibat chronic discomfort tersebut. Penerapan kaidah kesrawan dalam penelitian ini direpresentasikan dengan aplikasi teknik handling dan habituasi hewan coba terhadap seluruh proses pengukuran hemodinamika. Habituasi diawali dengan pengenalan hewan coba terhadap tangan operator dan dilanjutkan dengan habituasi terhadap apparatus hemodinamika, yaitu corong pengukuran. Variabel hemodinamika yang digunakan adalah tekanan darah sistolik, diastolik, frekuensi degup jantung, dan laju darah. Pengukuran hemodinamika dilakukan sebanyak tiga kali, yaitu sebelum diberikan perlakuan (T0), setelah dihabituasi terhadap sentuhan tangan operator (T1), dan setelah dihabituasi terhadap aparatus (corong) dari alat pengukur tekanan darah (T2). Enam dari tujuh tikus berdasarkan Uji Kruskal Wallis menunjukkan nilai signifikansi $(\mathrm{P}<0,05)$ untuk setiap variabel sistolik, diastolik, degup jantung, dan aliran darah pada perlakuan T0, T1, dan T2. Rataan nilai simpangan baku pada setiap variabel menunjukkan kecenderungan menurun, yaitu T0>T1>T2. Hal ini mengindikasikan bahwa pendekatan/metode berbasis kesrawan berpotensi memperbaiki kualitas hasil pengukuran yang diperoleh.
\end{abstract}

Kata-kata kunci: aliran darah; degup jantung; kesejahteraan hewan; tekanan darah

\begin{abstract}
Chronic discomfort potentially occurred during a hemodynamic measurements in a rat-tail blood pressure chamber due to the animal is restrained in restricted space for a long period - it took 10 repetitions each at approximately 1.5 minutes for a session of hemodynamic measure. Procedures related to the animal welfare methods are required to improve the accuracy of the measurement which would altered
\end{abstract}


from the discomfort to comfort state of the animal. Welfare procedures are represented by humane handling and habituation of the subject (rats) to the operator and the hemodynamic apparatus. Seven rats were subjected in this study and measured for hemodynamic value in three times point: before (T0), after humane handling (T1) and after human handling and habituation to the measurement apparatus (T2), respectively. Six out of seven subjects showed a significant lowering deviation for all variables of hemodynamic measurements, and that deviation followed by a declining trend from T0 to T2, i.e T0>T1>T2. The results indicated that welfare-based approach would benefit the animals from feeling discomfort and yet improving the accuracy and quality of the outcomes.

Keywords: animal welfare; blood pressure; blood flow; heart rate; variation

\section{PENDAHULUAN}

Perkembangan ilmu pengetahuan dan ilmu kesehatan mendorong penelitian yang menggunakan hewan sebagai subjek penelitian biomedis. Hewan coba sebagai makhluk hidup dapat merasakan nyeri seperti halnya manusia sehingga perlu diperlakukan dengan baik. Oleh karena itu, penggunaan hewan coba sebagai objek percobaan seharusnya menerapkan kaidah kesejahteraan hewan (kesrawan) (The 3R Center, 2015). Pengakuan pentingnya kesrawan termaktub dalam Undang-Undang Nomor 18 Tahun 2009. Undang-undang tersebut kemudian direvisi menjadi Undang-Undang Nomor 41 Tahun 2014 tentang Peternakan dan Kesehatan Hewan (Kemenkumham, 2014).

Konsep penelitian penggunaan hewan coba yang memenuhi kaidah kesrawan tersebut dikemukakan dengan komprehensif oleh pusat kajian 3R (The 3R Center, 2015), yaitu replacement, reduction, dan refinement. Penggantian atau penggunaan metode alternatif non-hewan adalah konsep replacement, sedangkan reduction diartikan sebagai penggunaan hewan coba dalam jumlah seminimal mungkin yang memberikan konklusi yang akurat. Prinsip refinement diwujudkan dengan prinsip lima kebebasan atau $5 \mathrm{~F}$ (five freedom) (FAWC 2009), yaitu bebas dari rasa lapar dan haus, bebas dari rasa ketidaknyaman kronik (chronic discomfort), bebas dari rasa sakit, luka, dan penyakit, bebas dari rasa takut dan stres, serta bebas untuk mengekspresikan tingkah laku alamiah hewan.

Penerapan kaidah kesrawan dalam penelitian yang meminimalisasi stres diharapkan memberikan hasil penelitian yang lebih akurat (Kaliokoski et al., 2012; Kurien et al., 2004; Veissier dan Boissy, 2007). Dalam studi yang dilaksanakan, penelitian vaskuler, khususnya pengukuran profil hemodinamika dengan hewan coba menjadi pilihan studi kesrawan mengingat pengukuran nilai hemodinamika menggunakan aparatus (seperangkat alat) pengukur tekanan darah ekor berpotensi menimbulkan cekaman dan ketidaknyamanan kronik_(Kalliokoski et al., 2013; Mineur et al., 2006). Cekaman memengaruhi kondisi fisiologis individu (Korte et al., 2007; Patki et al., 2013) mengingat hewan berada dalam corong aparatus yang memberikan ruang gerak sangat terbatas dan pengukuran berlangsung cukup lama, yaitu 10 kali ulangan pengukuran setiap sesi dan setiap pengukuran menghabiskan 1,5 menit, total waktu yang diperlukan adalah 15 menit. Selain waktu pengukuran, diperlukan waktu 10 menit sebelum pengukuran dilaksanakan untuk menghangatkan suhu tubuh hewan agar suhu di vena koksigea/ekor mencapai $30-32^{\circ} \mathrm{C}$. Hal ini diperlukan agar laju darah dapat dideteksi oleh alat tekanan darah.

Penerapan kesrawan diharapkan dapat mengurangi cekaman dan ketidaknyamanan yang dirasakan oleh hewan sehingga mampu meminimalisasi reaksi ketidaknyamanan yang ditimbulkan oleh hewan berupa gerak, suara, dan getaran. Keseluruhan reaksi tersebut dapat memengaruhi akurasi pengukuran profil hemodinamika dengan menggunakan aparatus (seperangkat alat) pengukur tekanan darah noninvasif yang sangat peka terhadap gerak, suara, cahaya, dan suhu. Akurasi dapat dilihat dari keseragaman data variabel hemodinamika dalam 10 kali ulangan tersebut, dalam hal ini ditentukan dengan melihat simpangan baku yang dihasilkan dari pengukuran tersebut.

Hal inilah yang mendorong dilakukannya penelitian mengenai pengaruh penerapan kesrawan pada akurasi pengukuran variabel hemaodinamika tekanan darah sistolik, diastolik, frekuensi degup jantung, dan aliran darah. Penerapan kesrawan dalam studi diimplementasikan dengan kendali hewan (restraint) yang sesuai kaidah kesrawan dan habituasi hewan uji, yaitu tikus putih galur Whistar, terhadap aparatus alat tekanan darah non-invasif CODA. Penelitian ini bertujuan untuk melihat serial pengaruh habituasi 
terhadap hewan coba melalui pengukuran variabel-variabel hemodinamika. Penerapan kaidah kesrawan diharapkan dapat memberikan hasil pengukuran variabel hemodinamika yang lebih seragam dengan simpangan baku yang lebih rendah.

\section{METODE PENELITIAN}

Penelitian ini menggunakan hewan coba tikus putih galur whistar, suatu galur tikus yang setiap generasinya mempunyai tingkat kemiripan genetik yang relatif tinggi, mencapai $98 \%$, meskipun sudah lebih dari 20 generasi (Maley dan Komasara, 2003). Tikus yang digunakan sebanyak tujuh ekor berumur 10 minggu dengan bobot badan 180-200 g, diperoleh dari PT Indo Anilab, Bogor. Seluruh prosedur pemeliharaan dan perlakuan telah dinyatakan lulus kaji etik oleh komisi etika hewan lokal Rumah Sakit Hewan Pendidikan Fakultas Kedokteran Hewan IPB dengan Nomor: 11-2015 ACUC RSHP FKH IPB.

Perlakuan pada penelitian ini berupa habituasi, yaitu pembiasaan tikus terhadap sentuhan tangan operator dan pembiasaan terhadap corong restrain hewan (animal holder) dari aparatus pengukur tekanan darah. Habituasi terhadap operator dilakukan setelah pengukuran hemodinamika awal (T0), hewan dikenalkan dengan sentuhan tangan operator setiap hari selama satu minggu kemudian dilakukan pengukuran hemodinamika kedua (T1). Selanjutnya, hewan dihabituasi selama satu minggu terhadap animal holder dengan cara memasukkan hewan ke dalam corong tersebut dan didiamkan selama 3 menit, kemudian dilakukan pengukuran hemodinamika ketiga (T2). Teknik habituasi disajikan pada Gambar 1.

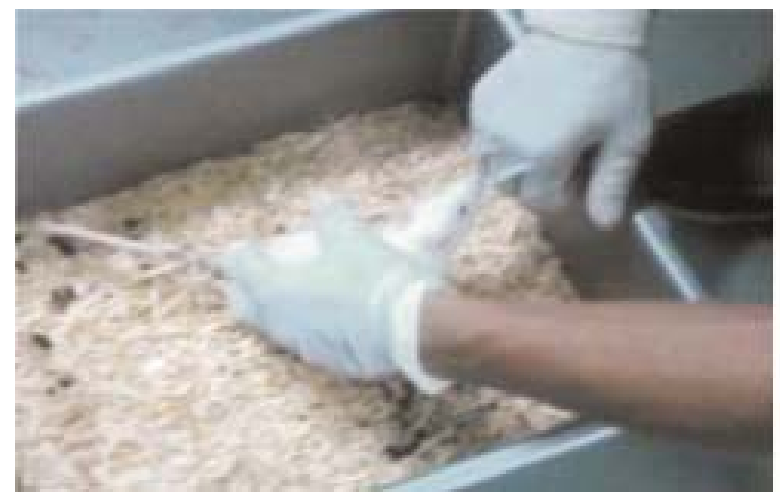

Pengukuran tekanan darah dilakukan tanpa anestesi menggunakan metode tail-cuff auto-pickup. Pengukuran seperti ini termasuk ke dalam metode non-invasif (Feng et al., 2008). Metode tersebut menggunakan sensor perekam tekanan volume darah (Feng, 2009). Perekam tekanan volume darah secara aktual mengukur enam variabel hemodinamika secara bersamaan, antara lain sistolik, diastolik, rataan (mean) tekanan arteri, degup jantung (heart rate), volume, dan aliran darah (blood flow) pada ekor tikus (Ciptaningsih, 2012) dalam studi ini, empat variabel yang dianalisis pada penelitian, yaitu sistolik, diastolik, degup jantung, dan aliran darah. Jumlah ulangan pengukuran adalah 10-15 kali pengukuran untuk setiap hewan uji.

Hasil pengukuran diuji distribusi normalnya dengan uji Kolmolgorov Smirnoff. Data yang memenuhi syarat dan terdistribusi normal, dilanjutkan dengan sidik ragam dan dilakukan uji lanjut Tukey, sedangkan uji Kruskal Wallis digunakan apabila data tidak yang terdistribusi secara normal. Seluruh analisis statistika menggunakan program SPSS 22.0 (Chicago, Illinois, USA).

\section{HASIL DAN PEMBAHASAN}

Rataan nilai hemodinamika yang diperoleh dari tiap-tiap perlakuan disajikan pada Tabel 1. Pengujian statistika non-parametrik dengan metode Kruskal Wallis dilakukan dengan pertimbangan sebaran dan homogenitas data individu tikus tidak memenuhi syarat uji sidik ragam. Pengujian Kruskal Wallis ini bertujuan untuk melihat ada atau tidaknya perbedaan yang signifikan antara T0, T1, dan T2 pada masing-masing tikus (secara individu).

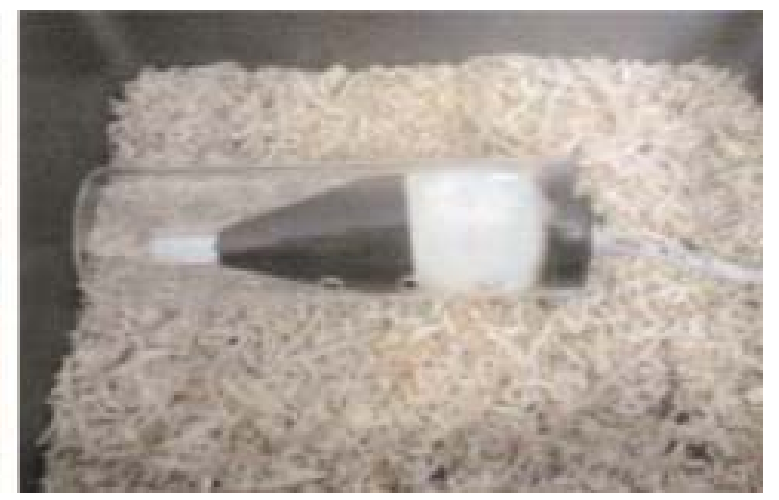

Gambar 1. Habituasi terhadap operator (a) dan habituasi terhadap animal holder (b) 
Tabel 1. Rataan nilai sistolik, diastoli, degup jantung, dan aliran darah pada ekor tikus.

\begin{tabular}{|c|c|c|c|c|c|c|c|c|c|c|c|c|}
\hline \multirow[t]{2}{*}{ Tikus } & \multicolumn{3}{|c|}{ Sistolik (mmHg) } & \multicolumn{3}{|c|}{ Diastolik (mmHg) } & \multicolumn{3}{|c|}{$\begin{array}{l}\text { Degup Jantung } \\
\text { (degup/menit) }\end{array}$} & \multicolumn{3}{|c|}{$\begin{array}{l}\text { Aliran Darah } \\
\text { (mL/menit) }\end{array}$} \\
\hline & T0 & $\mathrm{T} 1$ & $\mathrm{~T} 2$ & T0 & $\mathrm{T} 1$ & $\mathrm{~T} 2$ & T0 & $\mathrm{T} 1$ & $\mathrm{~T} 2$ & T0 & $\mathrm{T} 1$ & $\mathrm{~T} 2$ \\
\hline 1 & & & $188,67^{\mathrm{b}}$ & 86,07 & & $133,63^{b}$ & & & & 13,24 & 23,81 & $18,31^{\mathrm{b}}$ \\
\hline 2 & 5,00 & 137,20 & 141,14 & 1,64 & 96 , & 109,78 & 319,93 & 324 & 347 & 18,76 & & $21,40^{\mathrm{b}}$ \\
\hline 3 & & 127,57 & $120,00^{\mathrm{b}}$ & 5,80 & 94 & $78,60^{\mathrm{b}}$ & 246,50 & 315 , & & 3,86 & 21,57 & $25,25^{\mathrm{b}}$ \\
\hline 4 & & 130 & $131,67^{\mathrm{b}}$ & 76,55 & & $95,09^{\mathrm{b}}$ & & & 320 & 10,29 & 19,81 & $16,06^{\mathrm{b}}$ \\
\hline 5 & 3,20 & 112,88 & 99,9 & 73,67 & 83,55 & $63,60^{\mathrm{b}}$ & 298,23 & 316 & 313, & 14,76 & 15,40 & $20,63^{\mathrm{b}}$ \\
\hline 6 & 121,87 & 116,62 & $136,53^{\mathrm{b}}$ & 85,20 & 90,93 & $103,53^{b}$ & 301,62 & 339,44 & $344,36^{\mathrm{b}}$ & 20,38 & 20,68 & $25,64^{\mathrm{b}}$ \\
\hline 7 & 137,47 & 119,50 & $121,00^{\mathrm{b}}$ & 97,80 & 89,09 & $94,6^{\mathrm{b}}$ & 348,87 & 338,91 & $311,40^{\mathrm{b}}$ & 23,13 & 23,39 & $25,90^{b}$ \\
\hline Rataan & 118,79 & 125,17 & $134,13^{\mathrm{b}}$ & 83,82 & 90,90 & $96,98^{\mathrm{b}}$ & 304,65 & 334,10 & $328,11^{b}$ & 14,92 & 21,04 & 21,88 \\
\hline
\end{tabular}

Keterangan: T0= Tanpa perlakuan; T1: Habituasi terhadap operator; T2: Habituasi terhadap alat pengukur tekanan darah; b: Huruf superscript pada kolom T2 untuk setiap variabel menunjukkan data hemodinamika (secara individu) yang berbeda nyata antara T0, T1, dan $\mathrm{T} 2$

Enam dari tujuh tikus (>85,71\%) pada uji Kruskal Wallis menunjukkan nilai signifikansi yang berbeda nyata $(\mathrm{P}<0,05)$. Variabel sistolik memperlihatkan hasil yang berbeda nyata antara $\mathrm{T} 0, \mathrm{~T} 1$, dan $\mathrm{T} 2(\mathrm{P}<0,05)$ pada enam tikus, yaitu tikus 1 , tikus 3 , tikus 4 , tikus 5 , tikus 6 , dan tikus 7. Variabel diastolik memperlihatkan hasil yang berbeda nyata antara T0, T1, dan T2 $(\mathrm{P}<0.05)$ pada enam tikus, yaitu tikus 1 , tikus 3 , tikus 4 , tikus 5 , tikus 6 , dan tikus 7 . Variabel degup jantung memperlihatkan hasil yang berbeda nyata antara $\mathrm{T} 0, \mathrm{~T} 1$, dan $\mathrm{T} 2(\mathrm{P}<0.05)$ pada enam tikus, yaitu tikus 1 , tikus 2 , tikus 4 , tikus 5, tikus 6 , dan tikus 7 . Variabel aliran darah memperlihatkan hasil yang berbeda nyata antara T0, T1, dan T2 $(\mathrm{P}<0.05)$ pada enam tikus, yaitu tikus 1 , tikus 2 , tikus 3 , tikus 4 , tikus 5 , dan tikus 6 .

Nilai simpangan baku dari data sistolik, diastolik, degup jantung, dan aliran darah setiap tikus mengalami fluktuasi, disajikan pada Tabel 3. Secara umum, semua variabel memperlihatkan adanya penurunan nilai simpangan baku setelah dilakukan habitusi. Variabel sistolik yang memperlihatkan nilai simpangan baku T2 lebih kecil dibandingkan dengan T0 dan T1 terjadi pada tikus $1(3,66$ $\mathrm{mmHg})$, tikus $2(3,94 \mathrm{mmHg})$, tikus $6(11,76$ $\mathrm{mmHg})$, dan tikus $7(4,08 \mathrm{mmHg})$. Variabel diastolik yang memperlihatkan nilai simpangan baku T2 lebih kecil dibandingkan dengan T0 dan T1 terjadi pada tikus $1(3,46 \mathrm{mmHg})$, tikus 3 $(9,24 \mathrm{mmHg})$, tikus $6(9,46 \mathrm{mmHg})$, dan tikus 7 (3,70 $\mathrm{mmHg})$.

Variabel degup jantung yang memperlihatkan nilai simpangan baku T2 lebih kecil dibandingkan dengan T0 dan T1 terjadi pada tikus $3(18,96 \mathrm{degup} / \mathrm{menit}(\mathrm{d} / \mathrm{m})$, tikus $5(9,72$ $\mathrm{d} / \mathrm{m})$, tikus $6(9,24 \mathrm{~d} / \mathrm{m})$, dan tikus $7(4,38 \mathrm{~d} / \mathrm{m})$. Variabel aliran darah yang memperlihatkan nilai simpangan baku T2 lebih kecil dibandingkan dengan T0 dan T1 terjadi pada tikus $1(2,98 \mathrm{~mL} / \mathrm{menit})$, tikus $3(3,36 \mathrm{~mL} / \mathrm{m})$, tikus $4(2,26 \mathrm{~mL} / \mathrm{m})$, tikus $5(2,40 \mathrm{~mL} / \mathrm{m})$, tikus $6(4,20 \mathrm{~mL} / \mathrm{m})$, dan tikus $7(1,59 \mathrm{~mL} / \mathrm{m})$.

Simpangan baku yang mengalami penurunan pada T2 mengindikasikan data hemodinamika setelah habituasi terhadap animal holder lebih seragam dibandingkan dengan data hemodinamika sebelum dihabituasi (T0) dan data hemodinamika setelah dilakukan habituasi terhadap operator (T1). Grafik rataan nilai simpangan baku variabel sistolik, diastolik, degup jantung, dan aliran darah tersaji pada Gambar 2. Setiap variabel menujukkan kecenderungan rataan simpangan baku yang menurun pada $\mathrm{T} 1$ dan $\mathrm{T} 2$ dibandingkan dengan T0.

Rataan simpangan baku sistolik secara berurutan $\mathrm{T} 0(10,43 \mathrm{mmHg})>\mathrm{T} 1(8,63 \mathrm{mmHg})$ $>$ T2 $(7,98 \mathrm{mmHg})$. Rataan simpangan baku diastolik secara berurutan T0 $(9,25 \mathrm{mmHg})>$ $\mathrm{T} 1(7,55 \mathrm{mmHg})>\mathrm{T} 2(7,04 \mathrm{mmHg})$. Rataan simpangan baku denyut jantung secara berurutan T0 $(17,09 \mathrm{~d} / \mathrm{m})>\mathrm{T} 1(13,06 \mathrm{~d} / \mathrm{m})>$ $\mathrm{T} 2(12,50 \mathrm{~d} / \mathrm{m})$. Rataan simpangan baku aliran darah secara berurutan T0 $(4,12 \mathrm{ml} / \mathrm{m})>$ $\mathrm{T} 1(3,67 \mathrm{ml} / \mathrm{m})>\mathrm{T} 2(2,87 \mathrm{ml} / \mathrm{m})$. Kecenderungan simpangan baku yang menurun ini menunjukkan bahwa hewan coba (tikus) perlu dilakukan habituasi terlebih dahulu agar menghasilkan data yang lebih seragam. 
Tabel 3. Nilai simpangan baku sistolik, diastolik, degup jantung, dan aliran darah.

\begin{tabular}{|c|c|c|c|c|c|c|c|c|c|c|c|c|}
\hline \multirow[t]{2}{*}{ Tikus } & \multicolumn{3}{|c|}{ Sistolik (mmHg) } & \multicolumn{3}{|c|}{ Diastolik (mmHg) } & \multicolumn{3}{|c|}{$\begin{array}{c}\text { Degup Jantung } \\
\text { (degup/menit) }\end{array}$} & \multicolumn{3}{|c|}{$\begin{array}{c}\text { Aliran Darah } \\
(\mathrm{mL} / \mathrm{menit})\end{array}$} \\
\hline & T0 & $\mathrm{T} 1$ & $\mathrm{~T} 2$ & T0 & $\mathrm{T} 1$ & $\mathrm{~T} 2$ & T0 & $\mathrm{T} 1$ & $\mathrm{~T} 2$ & T0 & $\mathrm{T} 1$ & $\mathrm{~T} 2$ \\
\hline 1 & 16,97 & 7,69 & $3,66^{\mathrm{b}}$ & 9,32 & 6,13 & $3,46^{\mathrm{b}}$ & 9,15 & 12,11 & 11,28 & 4,70 & 6,58 & $2,98^{b}$ \\
\hline 2 & 10,41 & 5,71 & $3,94^{b}$ & 9,11 & 3,27 & 7,87 & 7,54 & 10,65 & 27,88 & 2,04 & 3,30 & 3,65 \\
\hline 3 & 9,61 & 28,61 & 18,83 & 12,02 & 19,37 & $9,24^{\mathrm{b}}$ & 59,60 & 37,34 & $18,96^{\mathrm{b}}$ & 3,98 & 3,82 & $3,36^{\mathrm{b}}$ \\
\hline 4 & 6,99 & 17,22 & 23,39 & 8,17 & 9,25 & 9,69 & 4,99 & 9,22 & 10,11 & 4,76 & 2,51 & $2,26^{\mathrm{b}}$ \\
\hline 5 & 6,05 & 4,73 & 6,46 & 7,75 & 10,59 & 9,29 & 13,18 & 21,37 & $9,72^{\mathrm{b}}$ & 3,43 & 3,22 & $2,40^{\mathrm{b}}$ \\
\hline 6 & 14,77 & 13,73 & $11,76^{\mathrm{b}}$ & 11,83 & 9,96 & $9,46^{\mathrm{b}}$ & 16,60 & 9,87 & $9,24^{\mathrm{b}}$ & 6,64 & 4,92 & $4,20^{\mathrm{b}}$ \\
\hline 7 & 8,19 & 5,91 & $4,08^{\mathrm{b}}$ & 6,55 & 3,90 & $3,70^{\mathrm{b}}$ & 8,56 & 14,95 & $4,38^{\mathrm{b}}$ & 3,31 & 2,43 & $1,59^{b}$ \\
\hline Rataan & 10,43 & 8,63 & 7,98 & 9,25 & 7,55 & 7,04 & 17,09 & 13,06 & 12,50 & 4,12 & 3,67 & 2,87 \\
\hline
\end{tabular}

Keterangan: huruf superscript pada kolom T2 menunjukkan simpangan baku yang mengalami penurunan dibandingkan dengan T0 dan $\mathrm{T} 1$.

Hasil berbeda nyata yang ditunjukkan oleh data individu pada mayoritas tikus $(>85,71 \%)$ cukup memperlihatkan bahwa ada kecenderungan pengaruh habituasi terhadap hemodinamika tekanan darah dan laju darah pada masing-masing individu tikus. Hal ini diperkuat dengan kecenderungan rataan nilai simpangan baku yang menurun pada T2 dibandingkan dengan T0 dan T1. Simpangan baku yang lebih kecil menunjukkan keseragaman hasil pengukuran. Pada T0, tikus belum terbiasa dengan alat pengukur tekanan darah sehingga lebih berpotensi menimbulkan stres saat proses pengukuran.

Pengujian terhadap hormon stres, kadar glukosa plasma, dan profil leukosit perlu dilakukan untuk memperkuat dugaan tersebut (Ishida et al., 2003; Kalliokoski et al 2012). Cekaman yang disebabkan oleh ketidaktersediaan pakan atau karena pengikatan dan pengangkutan hewan dapat meningkatkan hormon kortikosteron (Kusnadi, 2009; Larauche et al. 2010). Selain itu, salah satu respons dari dalam tubuh ketika terjadi stres adalah

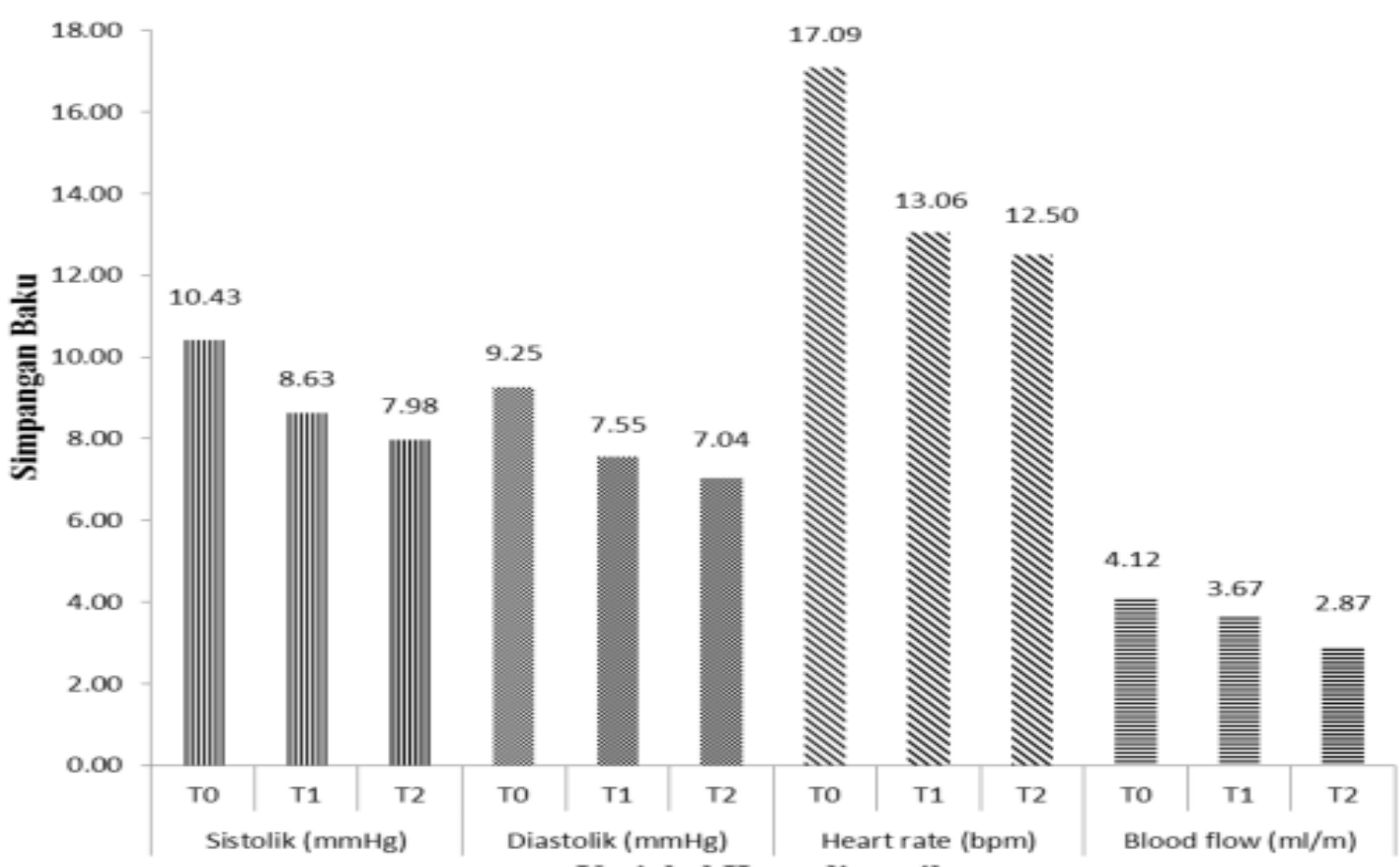

Variabel Hemodinamika

Gambar 2. Grafik rataan nilai simpangan baku setiap prameter sistolik, diastolik, degup jantung, dan aliran darah. Rataan nilai simpangan baku pada setiap variabel jika diurutkan menunjukkan kecenderungan menurun, yaitu T0>T1>T2. 
meningkatnya pelepasan glukokortikoid (Hau et al., 2011; Kainuma et al., 2009; Sundbom et al., 2011; Zhu et al., 2006) dan fungsi kardiovaskuler (Gillmore et al, 2008; Hoppe et al.,2009). Glukokortikoid dapat menghambat penyerapan glukosa oleh otot dan jaringan lemak (Andrew dan Walker, 1999; Bartolomucci et al., 2003) yang dapat menyebabkan kadar glukosa plasma meningkat (Lukman, 2008). Keadaan stres juga dapat meningkatkan jumlah leukosit darah tepi (Isnarni dan Sulistyani, 2010).

\section{SIMPULAN}

Aplikasi penanganan kendali hewan yang sesuai kaidah kesrawan berpotensi memperbaiki akurasi hasil pengukuran hemodinamika tekanan darah dan laju darah tikus putih galur Whistar melalui penurunan rataan nilai simpangan baku pada setiap variabel menunjukkan kecenderungan menurun.

\section{SARAN}

Penulis menyarankan untuk melakukan pengujian serupa dengan spesifikasi jenis kelamin dan variasi pengelompokan hewan coba untuk perlakuan habituasi yang berbeda. Selain itu, diperlukan pengujian lebih lanjut mengenai tingkat stres pada hewan coba melalui profil leukosit maupun kadar hormon stres.

\section{UCAPAN TERIMA KASIH}

Ucapan terima kasih kami sampaikan kepada Direktur Rumah Sakit Hewan Pendidikan, FKH IPB dan Program Bedah Saraf FK UI.

\section{DAFTAR PUSTAKA}

Andrew RC, Walker BR. 1999. Glucocorticoids and insulin resistance: old hormones, new targets. J Clin Sci 96: 513-523.

Bartolomucci A, Palanza P, Sacerdote P, Ceresini G, Chirieleison A. 2003. Individual housing induces altered immuno-endocrine responses to psychological stress in male mice. Psychoneuroendocrinology 28: 540558.
Ciptaningsih E. 2012. Uji aktivitas antioksidan dan karakteristik fitokimia pada kopi luwak arabika dan pengaruhnya terhadap tekanan darah tikus normal dan tikus hipertensi (Tesis). Depok. Universitas Indonesia.

[FAWC] Farm Animal Welfare Council. 2009. Five Freedoms - National Archives of United Kingdom Government [Internet]. [Diunduh 2017 Juni 3]; Tersedia pada http:// webarchive.nationalarchives.gov.uk/ 20121007104210/http:/www.fawc.org.uk/ freedoms.htm.

Feng M. 2009. Non-invasive blood pressure measurement in mice. In DiPetrillo, K. (Ed) Cardiovascular genomic, methods in molecular biology. New York: Humana Press. Hlm. 45-54.

Feng, M, Whitesall, S, Zhang, Y, Beibel, M, D'Alecy, L, DiPetrillo, K. 2008. Validation of Volume Pressure Recording Tail-Cuff Blood Pressure Measurements. Am J of Hyperten 10(301): 1-4.

Gilmore AJ, Billing RL, Einstein R. 2008. The effects on heart rate and temperature of mice and vas deferens responses to noradrenaline when their cage mates are subjected to daily restraint stress. Lab Anim 42: 140-148.

Hau J, Kalliokoski O, Jacobsen K, Abelson K. 2011. Interpretations of faecal concentrations of corticosteroids. Lab Anim 45: 129.

Hoppe CC, Moritz KM, Fitzgerald SM, Bertram JF, Evans RG. 2009. Transient hypertension and sustained tachycardia in mice housed individually in metabolism cages. Physiol Res 58: 69-75.

Ishida H, Mitsui K, Nukaya H, Matsumoto K, Tsuji K.2003. Study of active substances involved in skin dysfunction induced by crowding stress. I. Effect of crowding and isolation on some physiological variables, skin function and skin blood perfusion in hairless mice. Biol Pharm Bull 26: 170-181

Isnarni E, Sulistyani E. 2010. Perubahan jumlah leukosit darah tepi pada kondisi stres, penelitian eksperimental laboratories pada tikus whistar jantan. Stomatognatic (Jurnal Kedokteran Gigi Universitas Jember) 7(3): 45-48. 
Kainuma E, Watanabe M, Timiyama MC, Inoue M, Kuwano Y, Ren HW, Abo T. 2009. Assocition of glucocorticoid with stressinduced modulation of body temperature, blood glucose, and innate immunity. Psychoneuroendocrinology 34: 1459-1468.

Kaliokoski O, Jacobsen KR, Teilmann AC, Hau J, Abelson KA. 2012. Quantitative effects of diet on fecal corticosterone metabolites in two strains of laboratory mice. In Vivo 26(2): 213-21

Kaliokoski O, Jacobsen KR, Darusman HS, Henriksen T, Weinman A, Poulsen HE, Hau J, Abelson KA. 2013. Mice do not habituate to metabolism cage housing- a three weeks study of male BALB/C mice. Plos One 8(3): e58460.

[Kemenkumham] Kementerian Hukum dan Hak Asasi Manusia Republik Indonesia. 2014. Undang-undang nomor 8 tahun 2009 [Internet]. [Diunduh 2017 Juni 3] Tersedia pada: http://peraturan.go.id/uu/nomor-18tahun-2009.html.

Korte SM, Olivier B, Koolhas JM. 2007. A new animal welfare concept based on allostasis. Physiol Behav 92(3): 422-8.

Kurien BT, Everds NE, Scofield RH (2004) Experimental animal urine collection: a review. Lab Anim 38: 333-361.

Kusnadi E. 2009. Pengaruh Berbagai Cekaman terhadap Perubahan Beberapa Komponen dan Biokimia Darah Unggas. [Makalah Seminar]. Dalam: Prosiding Seminar Nasional Teknologi Peternakan dan Veteriner. Bogor (ID), 13-14 Agustus 2009. Hlm. 580-585.

Larauche M, Gourcerol G, Million M, Adelson DW, Tache Y. 2010. Repeated psychological stress-induced alterations of visceral sensitivity and colonic motor functions in mice: influence of surgery and postoperative single housing on visceromotor responses. Stress 13: 343-354

Lukman A. 2008. Mekanisme dan regulasi hormon glukokortikoid pada manusia. Biospecies 1(1): 25-28.

Maley K, Komasara L. 2003. VET 120 introduction to lab animal Science, Val Macer. [Internet]. [Diunduh 2015 Nov 18] Tersedia pada: http://www.medaille.edu/ vmacer/120_lab_rodent- lab1.htm.

Mineur YS, Belzung C, Crusio WE (2006) Effects of unpredictable chronic mild stress on anxiety and depression-like behavior in mice. Behav Brain Res 175: 43-50.

Patki G, Solanki N, Atrooz F, Allam F, Salim S. 2013. Depression, anxiety-like behavior and memory impairment are associated with increased oxidative stress and inflammation in a rat model of social stress. Brain Research 1539: 73-86.

Sundbom R, Jacobsen KR, Kalliokoski O, Hau J, Abelson KS. 2011. Postoperative Corticosterone Levels in Plasma and Feces of Mice Subjected to Permanent Catheterization and Automated Blood Sampling. In Vivo 25: 335-342.

The 3R center. 2015. William Russel and Rex Burch [Internet]. [Diunduh pada 30 Oktober 2017]. Tersedia pada http://en.3rcenter.dk/ 3r/russell-burch/

Veissier I, Boissy A. 2007. Stress and welfare: two complementary concepts that are intrinsically related to the animal's point of view. Physiol Behav 92(3): 429-33.

Zhu SW, Yee BK, Nyffeler M, Winblad B, Feldon J. 2006. Influence of differential housing on emotional behaviour and neurotrophin levels in mice. Behav Brain Res 169: 10-20. 